Four essays enlighten life transitions:

Egnew envisions that by helping patients to construct their illness stories, healers can help people dealing with chronic and terminal illness to transcend the suffering provoked by the degradations of their illness. ${ }^{16}$

Finklestein uses lived experience and an anthropologist's eye to reflect on the new life promised and pursued after a total colectomy for ulcerative colitis. ${ }^{17}$

Reuben explicates what might happen if the balance of physicians' responsibilities shift from transactional tasks toward personalized care. ${ }^{18}$

Loxterkamp presents a deeply personal yet universal reflection on the unrest and prospects of stepping back from a full life as a family physician into the as yet uncertain possibilities of retirement. ${ }^{19}$ I encourage multi-generational groups to use this article as a basis for personal and shared contemplation about loosening current attachments and being open to new possibilities. Please share the results of these reflections and discussions in the TRACK comments related to this essay.

We welcome you to join the online discussion for each of the articles at http://www.AnnFamMed.org.

\section{References}

1. Wong SYS, Sun YY, Chan ATY, et al. Treating subthreshold depression in primary care: a randomized controlled trial of behavioral activation with mindfulness. Ann Fam Med. 2018;16(2):111-119.

2. Yawn BP, Wollan PC, Rank MA, Bertram SL, Juhn Y, Pace W. Use of asthma APGAR tools in primary care practices: a cluster-randomized controlled trial. Ann Fam Med. 2018;16(2):100-110.

3. Yawn B, Bertram S, Wollan P. Introduction of asthma APGAR tools improves asthma management in primary care practices. J Asthma Allergy. 2008;1:1-10.

4. Rank MA, Bertram S, Wollan P, et al. Comparing the Asthma APGAR System and the Asthma Control Test in a multicenter primary care sample. Mayo Clin Proc. 2014;89(7);917-925.
5. Liddy C, Moroz I, Afkham A, Keely E. Sustainability of a primary care-driven eConsult service. Ann Fam Med. 2018;16(2):120-126.

6. Mercer SW, Zhou Y, Humphris GM, et al. Multimorbidity and socioeconomic deprivation in primary care consultations. Ann Fam Med. 2018;16(2):127-131.

7. Smith SM, Wallace E, Salisbury C, Sasseville M, Bayliss E, Fortin M. A core outcome set for multimorbidity research (COSmm). Ann Fam Med. 2018;16(2):132-138

8. Fedewa SA, Gansler T, Smith R, et al. Recent patterns in shared decision making for prostate-specific antigen testing in the United States. Ann Fam Med. 2018;16(2):139-144.

9. Naji L, Randhawa H, Sohani Z, et al. Digital rectal examination for prostate cancer screening in primary care: A systematic review and meta-analysis. Ann Fam Med. 2018;16(2):149-154.

10. Harrington R, Adimadhyam S, Lee TA, Schumock GT, Antoon JW. The relationship between oseltamivir and suicide in pediatric patients. Ann Fam Med. 2018;16(2):145-148.

11. Mold JW, Blake GH, Becker LA. Goal-oriented medical care. Fam Med. 1991;23(1):46-51.

12. Mold JW. Achieving Your Personal Health Goals: A Patient's Guide. Englewood Cliffs, California: Full Court Press; 2017.

13. Nagykaldi ZJ, Tange H, De Maeseneer J. Moving from problemoriented to goal-directed health records. Ann Fam Med. 2018;16(2): 155-159.

14. Kiran T, Davie $S$, MacLeod P. Citizen engagement in primary care. Ann Fam Med. 2018;16(2):175.

15. Panzer J. Ordering labs as a team. Ann Fam Med. 2018;16(2):176.

16. Egnew TR. A narrative approach to healing chronic illness. Ann Fam Med. 2018;16(2):160-165.

17. Finkelstein A. You will have a new life. Ann Fam Med. 2018;16(2): 166-167.

18. Reuben DB, Sinsky CA. From transactional tasks to personalized care: a new vision of physicians' roles. Ann Fam Med. 2018;16(2): 168-170.

19. Loxterkamp D. When it's time to retire: notes from the afterlife. Ann Fam Med. 2018;16(2):171-174.

\title{
Thank you, Reviewers and E-letter Contributors!
}

Ann Fam Med 2018;16:99. https://doi.org/10.1370/afm.2225.

We would like to extend our thanks to two groups who provide invaluable insights to the Annals of Family Medicine.

Peer reviewers are key to advancing scholarship and contributing to the quality of a research journal. We are grateful to the many individuals who volunteer their time and expertise in this important endeavor. Please see https://www.annfammed.org/sites/default/files/additional_assets/PDF\%20Documents/PDF/reviewers17.pdf for the names of the Annals' 2017 peer reviewers.

The Annals is also enriched by those who contribute e-letters. In 2017, we posted 117 e-letters reflecting on a wide range of published articles. Our sincere thanks to those who participated in this stimulating dialogue. To read e-letters, click on the eLetters tab on the right-hand side of any article. 